\title{
Therapeutic use of stem cells in Mexico: Status and perspectives
}

\author{
Alejandro García-Ruiz ${ }^{1,2 *}$ and Celia N. Sánchez-Domínguez ${ }^{1}$ \\ ${ }^{1}$ Department of Biochemistry and Molecular Medicine, Universidad Autónoma de Nuevo León, Monterrey, Nuevo Leon, Mexico; ${ }^{2}$ Department of \\ Therapeutic Radiology, School of Medicine, Yale University, New Haven, USA
}

\begin{abstract}
The use of stem cells (SCs) is one of the most promising strategies for multiple human affections due to its properties such as proliferation, migration through the tissue, immune system modulation, and differentiation potential. SC can differentiate into the cellular lineages of the organism, which gives them a potential use for restoration of damaged tissue due to acute or chronic factors and immune diseases. Due to these properties, SC has been evaluated in more than 6700 clinical trials worldwide, including Mexico. Actual research has not clarified all the biological mechanisms that control SCs so that there are multiple risks involved in SC treatments, which patients need to consider before approaching said treatments. There is also a lack of legislation for these treatments, which despite having a real potential therapeutic effect, propitiates the establishment of medical treatments that do not guarantee safety and efficacy, so patients should consider the risks and benefits before a procedure. This review intends to provide an overview of SC characteristics, identification, actual and future SC treatments, and information about non-regulated SC therapies and possible side effects.
\end{abstract}

Key words: Stem cells. Clinical trials. Stem cell tourism.

\section{Introduction}

Stem cells (SCs) are undifferenced cells that possess the ability to proliferate, migrate, and differentiate to the human body's cellular lineages ${ }^{1}$. In the clinic, these cells are mostly used due to their immunomodulatory abilities, which are able to regulate inflammation control processes, allowing tissue maintenance and renovation ${ }^{2}$.

SC use and manipulation, through chemical agents and growth factors, have promoted its application in the regenerative medicine field, where the expectation is to accomplish the differentiation of these cells toward different cellular lineages with the intention of replacing lost cells from acute or chronic damage processes, something that is currently being evaluated in several clinical essays in Mexico and around the world ${ }^{3}$.

This revision's main objective is to offer a general overview of SCs, their characteristics, current and future clinical uses, and the necessary information regarding their safety and efficacy for the discrimination between clinical treatments offered commercially.

\section{SCs: origin and properties}

SCs derive from the germinative layers formed during the embryogenesis process. They are preserved in

\section{Correspondence:}

*Alejandro García-Ruiz

E-mail: alejandro.garciaruiz@yale.edu license (http://creativecommons.org/licenses/by-nc-nd/4.0/).
Date of reception: 04-01-2021

Date of acceptance: 12-02-2021

DOI: 10.24875/RMU.21000001
Available online: 18-03-2021

Medicina Universitaria. 2021;23(1):18-23 www.medicinauniversitaria.org 


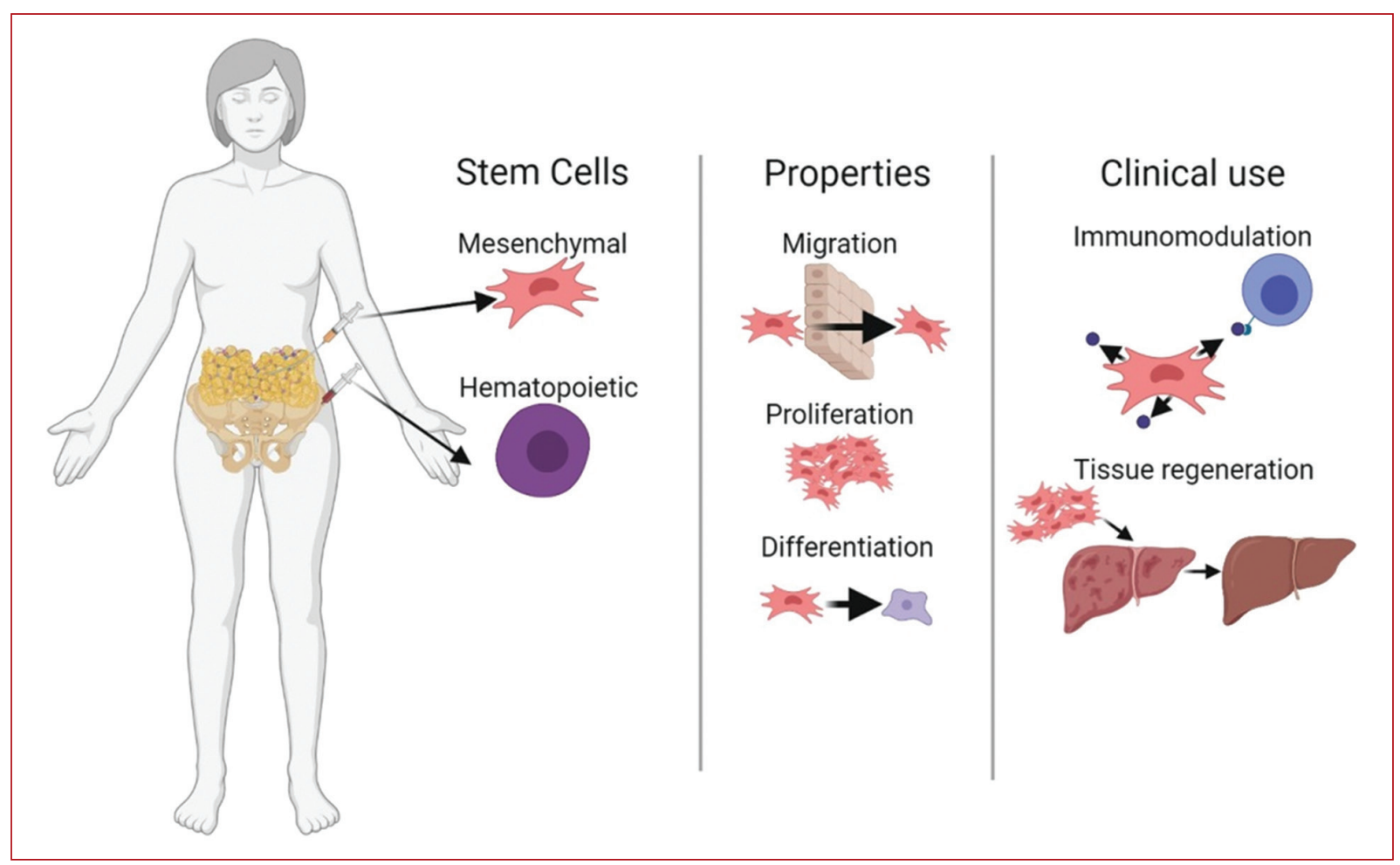

Figure 1. Stem cell overview: isolation, properties, and clinical use. The most representative SC groups are mesenchymal and hematopoietic cells, which can be isolated from fat tissue and bone marrow, respectively. These cells have migration, proliferation, and differentiation properties that make possible their clinical use as an immunomodulatory mechanism and for tissue regeneration.

multiple tissues until adult development, with a greater or lesser degree of differentiation ${ }^{4}$, to be used by the organism for wound repair and tissue restoration. However, their natural regenerative capabilities are limited due to their low proportion in the tissue and a possible lack of proper stimulation by the injured tissue. Therefore, SC isolation and concentration or proliferation were proposed as an advanced therapy with the possibility of relieving a large part of human injuries and diseases ${ }^{5}$.

This cellular type has extensive properties that make it highly desirable for therapeutic use (Fig. 1), which are described in detail below:

\section{Immunomodulator properties}

SCs possess a paracrine activity capable of modulate the immune system and reduce inflammation processes, allowing tissue restoration in damaged zones. This paracrine capability is due to the constitutive secretion of anti-inflammatory factors in extracellular vesicles $^{6}$, among which are cytokines with anti-inflammatory capabilities such as prostaglandin 2, interleukin 10, and the granulocyte colony-stimulating factor ${ }^{7}$, as well as factors with the ability to change the macrophages M1 pro-inflammatory phenotype to M2 anti-inflammatory phenotype ${ }^{8}$ and suppress the activation of neutrophils, dendritic cells, NK cells, and T cells ${ }^{9}$. All this, allows for its potential use in degenerative diseases linked to autoimmune disorders, such as Crohn's disease, systemic erythematous lupus, and transplant rejection ${ }^{10}$, including central nervous system disorders mediated by the abnormal activation of glial cells and immune infiltration ${ }^{11}$, being able to moderate neuronal loss in diseases such as amyotrophic lateral sclerosis and Alzheimer's and Parkinson's diseases.

\section{Cellular migration}

SCs have the ability to migrate through circulation and penetrate specific tissues through a mechanism known as "homing," where the cells travel in the bloodstream until locating the damage and inflammation sites, to perform their extravasation inside the endothelium ${ }^{12}$, being recruited through attracting chemokines involved in the inflammation process, as the 
stroma-derived factor- $1^{13}$, migrating through the interaction of the VL-4 antigen with vascular adhesion proteins $(\mathrm{VCAM}-1)^{13}$, followed by the secretion of metalloproteinases to help penetrate the basal membrane of the tissues at the target sites. However, the exact mechanisms of the migration process have not been completely elucidated, and its application in circulation does not ensure that the cells will migrate specifically to the desired sites.

\section{Differentiation capabilities}

SCs are capable of differentiate to all other existent somatic cells of human organism ${ }^{14}$. Once isolated from a tissue, they can be transformed into specific cells from a completely different organ or tissue and comply with the particular functions of this other lineage $^{15}$. Biologically, this differentiation process responds to signals or stimuli from the microenvironment or biologic niche, which provides optimal stimulation so that SCs begin their differentiation process $^{16,17}$. Interestingly, SC can be induced to their differentiation in vitro through the use of chemical agents and growth factors, so the optimization of culture techniques, as well as proper stimulation, is necessary for the purpose of imitating the biological conditions of SC differentiation ${ }^{18,19}$.

\section{Types of SCs}

SCs are subdivided into different categories according to their differentiation potential2:

- Totipotent - with the ability to divide itself and produce all the cellular lineages of the organism, as well as the capability to form a complete organism. They come from the zygote and are considered embryonic SC.

- Pluripotent - capable of differentiate to the derived lineages of the three germinative layers (ectoderm, endoderm, and mesoderm), without the ability to form a complete organism.

- Multipotent: capable of differentiate into multiple specific cellular lineages of one of the germinal layers, such as hematopoietic, neuronal, intestinal, and mesenchymal SCs. They remain in the body as a regeneration mechanism for damaged tissue and can be isolated from different tissues in the human body, such as bone marrow, dental pulp, skin, umbilical cord, or adipose tissue. They can be isolated and expanded in-culture for their clinical use 20,21 .

\section{SCs and their use in clinical treatments}

Globally, the first clinical treatment with SC was the bone marrow transplant, which consists of the replacement of hematopoietic SCs for the treatment of hematological diseases, with over 50,000 procedures performed every year ${ }^{22}$.

At present, SC application is being proposed in other medical conditions, as patients with vascular dysfunction etiologies (erectile dysfunction), ischemic diseases with decrease in cardiac contraction, and chronic ulcer treatments, among others ${ }^{23-25}$.

Using the database of clinical essays at the United States' National Health Institute ${ }^{26}$, at the moment of the completion of this review, there are over 6700 interventional clinical studies of SCs which are active worldwide; of which, 2679 are completed, 700 with significant results and 209 were approved for use by the Food and Drug Administration (FDA).

In Mexico's case, there are a total of 43 clinical essays with SC (15 in international collaboration) for conditions such as amyotrophic lateral sclerosis, diabetes, cardiac damage, brain damage, Parkinson's disease, leukemia, myeloma, and osteoarthritis. Only 12 essays have been completed, 5 of them with significant results, and none have been approved by the FDA.

Interestingly, over $50 \%$ of these clinical studies of SC in Mexico have been conducted with the collaboration of the "Dr. Jose E. Gonzalez" University Hospital, followed by the National Institute of Medical Sciences and Nutrition "Salvador Zubiran" (21\%).

Moreover, the clinical use of SCs has shown diverse results, which have not always been satisfactory, generating inconclusive results or a lack of significant benefit for patients. There were cases where it became necessary to terminate said treatments or clinical essays due to adverse side effects ${ }^{27}$. Thus, many SC treatments are legally limited in different countries, and many patients seek SC treatments in other countries with a more lax regulation, especially in Latin America, Asia, and the Caribbean, known as medical tourism or SC tourism ${ }^{28}$.

\section{SC tourism}

SC tourism implies the travel of individuals to other countries in search of SC therapies that are not approved in their country of origin or which are significantly cheaper; however, the search of active treatments under less strict regulation can compromise patients' safety ${ }^{29}$. The main causes or diseases which motivate individuals 
to seek SC tourism include terminal diseases and medical conditions such as multiple sclerosis, cerebral palsy, spinal cord injury, and Parkinson's disease ${ }^{28,30}$.

The search for less regulated therapeutic options increases the risks associated to the treatment, such as the risk of infections, thrombosis, excessive proliferation of utilized cells, and even the possibility of a tumor formation or tissue growth at an incorrect site ${ }^{31}$. In addition, there are economic risks where the patients invest their financial capital, many times without receiving a significant benefit in return ${ }^{32}$.

There are SC therapy centers shut down by the FDA due to inadequate practices, which have pursued moving to countries with a loose regulation on biological products to continue operating ${ }^{31}$. The fact that these types of clinics are functioning under a more relaxed regulation, including interventions with SC culture and/ or the use of embryonic cells, has resulted in adverse effects, where at 2017, a total of 35 cases with chronic and/or severe acute complications were reported as a result of the use of $\mathrm{SC}^{28,33}$.

To verify the safety of a therapy, it is necessary to: (a) confirm the accreditation of the clinic or hospital which one is planning to visit, (b) its infrastructure, (c) personnel qualifications, and (d) accessibility to the results of clinical studies, both favorable and unfavor$a_{b l e}{ }^{34}$. For that purpose, it is recommended that the patients request for the full information about the identification of the cells to use and the quality controls utilized during all stages of treatment, as well as to demand the complete documentation of how the procedure was performed, so that, in case of an adverse reaction, the treating doctors can diagnose the situation more efficiently.

Mexico has been one of the most sought countries for SC tourism ${ }^{32}$, since up to this point, the existing legislation regarding its use in clinical therapies is scarce. This lack of regulation difficulties the discrimination between treatments carried out by competent institutions, and those where safety and efficacy have not been proven.

Despite, in Mexico, there are certified health centers and hospitals, with personnel properly qualified to perform SC isolation and application procedures, centers that comply with permits and credentials dictated by the Federal Commission for the Protection Against Sanitary Risks (COFEPRIS by its Spanish acronym) for establishments dedicated to regenerative medicine ${ }^{35}$ and/or establishments with the disposition of $\mathrm{SCs}^{36}$. These institutions also publish their results in medical journals, hence, benefiting the patients as well as the scientific community. Some examples of these places are - The Hematology Service at the "Dr. Jose E. Gonzalez" University Hospital, the "Salvador Zubiran" National Institute of Medical Sciences and Nutrition, the "La Raza National Medical Center," the "Federico Gómez," and Children's Hospital of Mexico or the "Ignacio Chavez" National Institute of Cardiology, to name a few.

\section{Legal framework of SC treatment in Mexico}

Regarding the national normative framework for SC treatment, there is a project of Official Mexican Norm (NOM) "For the provision of SC and progenitor cells with therapeutic and research purposes" (NOM-260SSA1-2015), which contemplates the legislation of SC with international standards which guarantee quality and safety concerning the obtainment, evaluation, processing, storage, and provision of these cells. However, said project has not been approved. Thus, today, the only legislation available is the reforms to the General Health Law.

The National Academy of Medicine points out the need to regulate $S C$ treatments, to guarantee treatment quality and patient safety; it is necessary to resume proper legislation of the use of SC through the approval of the NOM-260-SSA1-2015 ${ }^{37}$.

The legislation of SC treatments should not seek to make scientific research into this topic difficult, rather regulate the establishments and procedures that ensure patient safety, requiring the presentation of real proof of its functioning and specific identification of the SC as dictated by the International Society of Cellular and Genetic Therapy (ISCT), considering the presence of membrane markers such as CD44+, CD90+, and CD105+ for mesenchymal cells and their capability of differentiation to chondrocyte, bone, and adipose lineages ${ }^{38}$.

It is important that the studies with SC ought to focus also on determining therapeutic mechanisms and treatment safety, as well as specific factors such as dose and frequency of use, which lead to a better clinical result as well as the identification of the most adequate cellular type for the type of tissue to treat, to accomplish safe and efficient future therapies, and to minimize potential risks of treatment ${ }^{23,24}$.

\section{Potential health risks in SC treatment}

One of the most concerning health risks derived from the use of SC treatments is the possibility that the transplanted cells create tumors or abnormal growth in the tissue ${ }^{39}$. This can be because their qualities are 
similar to those of tumor cells, such as their extensive proliferation capability, undifferentiated state, and resistance to apoptosis ${ }^{40}$. Nevertheless, even though there are isolated cases of this type of abnormal growth in the tissue, these are very rare.

Another type of risk with the use of SC is immunological risks. The use of autologous SCs does not represent a problem since isolated cells used for treatment are from the same patient who is receiving them. However, in the case of allogenic therapy, where the cells belong to a different patient, there is the possibility that the cells can induce an immune response since, despite presenting a low level of major histocompatibility complex and their capability of modulating the immune system, they are often rejected by the host's immune system ${ }^{41}$. One option for dealing with this problem is the administration of immunosuppressors, yet this can decrease the effectiveness of cellular therapy and increase the risk of infection.

In addition to the inherent risk of the use of SC, there is the risk of contamination during SC isolation or culture in the laboratory (by bacteria, virus, or fungus), increasing the probability of developing infections (local or systemic) during the surgical procedure, together with the possible immunosuppression treatment to avoiding rejection of the $\mathrm{SC}^{40,42}$.

\section{Conclusion}

There is great therapeutic potential for the use of SC, with significant results globally, as well as nationally. However, these new therapies are still in development in many Latin American countries, including Mexico. Thus, it is necessary to have a legislation that regulates said therapies before being utilized in clinical practice. To accomplish this objective, the development of new research is necessary, both in basic science (to comprehend the biology of SCs) and translational studies and clinical essays, which guarantee the efficacy and safety of SC treatments.

\section{Acknowledgments}

The authors express their gratitude to Dr. Irma G. Dominguez-Vigil for her valuable suggestions to improve this article.

\section{Conflicts of interest}

The authors declare not to have any conflicts of interest.

\section{Financing}

The present research did not receive any specific scholarship from any public, commercial, or non-profit agencies.

\section{Ethical disclosures}

Protection of human and animal subjects. The authors declare that no experiments were performed on humans or animals for this study.

Confidentiality of data. The authors declare that no patient data appear in this article.

Right to privacy and informed consent. The authors declare that no patient data appear in this article.

\section{References}

1. Oyarzun E. Células madres: nuevas fronteras para la medicina. Rev Chil Obstet Ginecol. 2005;70:211-2.

2. Dulak J, Szade K, Szade A, Nowak W, Józkowicz A. Adult stem cells: hopes and hypes of regenerative medicine. Acta Biochim Pol. 2015;62:329-37.

3. Walker JM. In: Gnecchi M, editor. Mesenchymal Stem Cells. $2^{\text {nd }}$ ed. New York: Springer; 2016.

4. Bhartiya D. Pluripotent stem cells in adult tissues: struggling to be acknowledged over two decades. Stem Cell Rev Rep. 2017:13:713-24.

5. Krinner A, Roeder I. Quantification and modeling of stem cell-niche interaction. Adv Exp Med Biol. 2014;844:11-36.

6. Lo Sicco C, Reverberi D, Balbi C, Ulivi V, Principi E, Pascucci L, et al. Mesenchymal stem cell-derived extracellular vesicles as mediators of anti-inflammatory effects: endorsement of macrophage polarization. Stem Cells Transl Med. 2017;6:1018-28.

7. Redondo-Castro E, Cunningham C, Miller J, Martuscelli L, Aoulad-Ali S, Rothwell NJ, et al. Interleukin-1 primes human mesenchymal stem cells towards an anti-inflammatory and pro-trophic phenotype in vitro. Stem Cell Res Ther. 2017:8:79.

8. Murphy KC, Whitehead J, Falahee PC, Zhou D, Simon SI, Leach JK. Multifactorial experimental design to optimize the anti-inflammatory and proangiogenic potential of mesenchymal stem cell spheroids. Stem Cells. 2017;35:1493-504.

9. Hamid T, Prabhu SD. Immunomodulation is the key to cardiac repair. Circ Res. 2017;120:1530-2.

10. Wang M, Yuan Q, Xie L. Mesenchymal stem cell-based immunomodulation: properties and clinical application. Stem Cells Int. 2018;2018:3057624.

11. Chen X, Wang S, Cao W. Mesenchymal stem cell-mediated immunomodulation in cell therapy of neurodegenerative diseases. Cell Immunol. 2018;326:8-14.

12. Karp JM, Leng Teo GS. Mesenchymal stem cell homing: the devil is in the details. Cell Stem Cell. 2009;4:206-16.

13. Zachar L, Ba冈enková D, Rosocha J. Activation, homing, and role of the mesenchymal stem cells in the inflammatory environment. J Inflamm Res. 2016;9:231-40.

14. Rossant J, Tam PP. New Insights into early human development: lessons for stem cell derivation and differentiation. Cell Stem Cell. 2017;20:18-28.

15. Sobhani A, Khanlarkhani N, Baazm M, Mohammadzadeh F, Najafi A, Mehdinejadiani $S$, et al. Multipotent stem cell and current application. Acta Med Iran. 2017;55:6-23.

16. Pantoja MD, Romero-Ramirez H, Carlos J, Alba R. Células Madre $\mathrm{He}-$ matopoyéticas: origen, Diferenciación y Función; 2015.

17. Singh A, Singh A, Sen D. Mesenchymal stem cells in cardiac regeneration: a detailed progress report of the last 6 years $(2010-2015)$. Stem Cell Res Ther. 2016;7:1-25

18. Almalki SG, Agrawal DK. Key transcription factors in the differentiation of mesenchymal stem cells. Differentiation. 2016;92:41-51.

19. Somoza RA, Welter JF, Correa D, Caplan Al. Chondrogenic differentiation of mesenchymal stem cells: challenges and unfulfilled expectations. Tissue Eng Part B Rev. 2014;20:596-608.

20. Uccelli A, Moretta L, Pistoia V. Mesenchymal stem cells in health and disease. Nat Rev Immunol. 2008;8:726-36.

21. Argentati C, Morena F, Bazzucchi M, Armentano I, Emiliani C, Martino S. Adipose stem cell translational applications: from bench-to-bedside. Int $\mathrm{J}$ Mol Sci. 2018;19:3475

22. Bazinet A, Popradi G. A general practitioner's guide to hematopoietic stem-cell transplantation. Curr Oncol. 2019;26:187-91. 


\section{A. García-Ruiz, C.N. Sánchez-Domínguez: Therapeutic use of stem cells in Mexico}

23. Gómez-Guerra LS, Robles-Torres Jl, Garza-Bedolla A, Mancías-Guerra C. Erectile dysfunction treated with intracavernous stem cells: a promising new therapy? Rev Int Androl. 2018;16:119-27.

24. Lara-Martínez LA, Gutiérrez-Villegas I, Arenas-Luna VM, Hernández-Gutierrez S. Stem cells: searching predisposition to cardiac commitment by surface markers expression. Arch Cardiol Mex. 2018;88:483-95.

25. Mejía-Barradas CM, Cázares-Montañez JE, Guerra-Márquez Á, Hernández-Chávez VG, Cáceres-Cortés JR, Gutiérrez-Iglesias G. Regenerative treatment with umbilical cord mesenchymal stem cells from Wharton's jelly in chronic ulcer caused by dermolipectomy. Cir y Cir (English Ed). 2019;87:8-16.

26. National Institutes of Health. Clinical Trials. Washington, DC: National Institutes of Health

27. Schwartz PJ. How reliable are clinical trials? The importance of the criteria for early termination. Eur Heart J. 1995;16:37-45.

28. Matthews KR, Iltis AS. Unproven stem cell-based interventions and achieving a compromise policy among the multiple stakeholders. BMC Med Ethics. 2015;16:1-11.

29. Cesario SK. Implications of medical tourism. Nurs Womens Health 2018;22:269-73.

30. Master Z, Robertson K, Frederick D, Rachul C, Caulfield T. Stem cell tourism and public education: the missing elements. Cell Stem Cell. 2014:15:267-70.

31. Cuchiara ML, Olive JK, Matthews K. Regulating the therapeutic translation of regenerative medicine. Expert Opin Biol Ther. 2015;15:1387-90.

32. Zarzeczny A, Rachul C, Nisbet M, Caulfield T. Stem cell clinics in the news. Nat Biotechnol. 2010;28:1243-6.

33. Bauer G, Elsallab M, Abou-El-Enein M. Concise review: a comprehensive analysis of reported adverse events in patients receiving unproven stem cell-based interventions. Stem Cells Transl Med. 2018;7:676-85.
34. Leggat P. Medical tourism. Aust Fam Physician. 2015;44:16-21.

35. COFEPRIS. Licencia Sanitaria para Establecimientos de Medicina Regenerativa; [Internet]. 2017 [cited 2021 Feb 4]. Available from: https://www.gob.mx/cms/uploads/attachment/file/411722/SEASS REGEN.pdf

36. COFEPRIS. Licencia Sanitaria para Establecimiento de Atención Médica con Disposición y/o Banco de Organos, Tejidos y Células; [Internet]. 2017 [cited 2021 Feb 4]. Available from: https://www.gob.mx/cms/uploads/attachment/file/322872/SEASS_TRASP.pdf.

37. Mansilla-Olivares A, Rojo J, de Medina MJ, Valenzuela-Gómez-Gallardo F, López-Bárcena J, Meneses-González F, et al. Posición de la Academia Nacional de Medicina de México con el fin de regular el uso de células troncales y de embriones humanos para fines terapéuticos o de investigación. Gac Med Mex. 2018;154:729-31.

38. Dominici M, Le Blanc K, Mueller I, Slaper-Cortenbach I, Marini F, Krause D, et al. Minimal criteria for defining multipotent mesenchymal stromal cells. The international society for cellular therapy position statement. Cytotherapy. 2006:8:315-7.

39. Woodworth CF, Jenkins G, Barron J, Hache N. Intramedullary cervical spinal mass after stem cell transplantation using an olfactory mucosal cell autograft. CMAJ 2019;191:E761-4.

40. Mousavinejad M, Andrews PW, Shoraki EK. Current biosafety considerations in stem cell therapy. Cell J. 2016;18:281-7.

41. Nasef A, Ashammakhi N, Fouillard L. Immunomodulatory effect of mesenchymal stromal cells: possible mechanisms. Regen Med 2008;3:531-46.

42. Sahin U, Toprak SK, Atilla PA, Atilla E, Demirer T. An overview of infectious complications after allogeneic hematopoietic stem cell transplantation. J Infect Chemother. 2016;22:505-14. 